\title{
The Impact of Sectoral Development on Natural Forest Conversion and Degradation: The Case of Timber and Tree Crop Plantations in Indonesia
}

Hariadi Kartodihardjo and Agus Supriono

CENTER FOR INTERNATIONAL FORESTRY RESEARCH

Office address: Jalan CIFOR, Situ Gede, Sindang Barang, Bogor 16680, Indonesia

Mailing address: P.O. Box 6596 JKPWB, Jakarta 10065, Indonesia

Tel.: +62 (251) 622622; Fax: +62 (251) 622100

E-mail: cifor@cgiar.org

Website: http://www.cgiar.org/cifor 


\section{The CGIAR System}

The Consultative Group on International Agricultural Research (CGIAR) is an informal association of 41 public and private sector donors that supports a network of sixteen international agricultural research institutes, CIFOR being the newest of these. The Group was established in 1971. The CGIAR Centers are part of a global agricultural research system which endeavours to apply international scientific capacity to solving of the problems of the world's disadvantaged people.

\section{CIFOR}

CIFOR was established under the CGIAR system in response to global concerns about the social, environmental and economic consequences of loss and degradation of forests. It operates through a series of highly decentralised partnerships with key institutions and/or individuals throughout the developing and industrialised worlds. The nature and duration of these partnerships are determined by the specific research problems being addressed. This research agenda is under constant review and is subject to change as the partners recognise new opportunities and problems. 


\section{Contents}

$\begin{array}{lr}\text { Abstract } & 1 \\ \text { Introduction } & 1 \\ \text { Timber and tree crop plantations } & 2 \\ \text { Timber plantations } & 2 \\ \text { Tree crop plantations } & 3 \\ \text { Natural forest conversion } & 4 \\ \text { Natural forest degradation by HPHs } & 5 \\ \text { Allocation of conversion forest } & 7 \\ \text { Encroachment of conservation and protection forests } & 7 \\ \text { Analysis of timber and tree crop } & \\ \text { plantation policies } & 8 \\ \text { Timber extraction from conversion forests } & 8 \\ \text { Agrarian disputes and their social impact } & 8 \\ \text { Controversies in timber plantation policy } & 9 \\ \text { Forest land use policy } & 10 \\ \text { Policy changes in the reformation era } & 10 \\ \text { Recommendations and findings } & 11 \\ \text { Summary of findings } & 11 \\ \text { Recommendations } & 11 \\ \text { Acknowledgements } & 12 \\ \text { Endnotes } & 12 \\ \text { References } & 14\end{array}$




\title{
The Impact of Sectoral Development on Natural Forest Conversion and Degradation: The Case of Timber and Tree Crop Plantations in Indonesia
}

\author{
Hariadi Kartodihardjo* and Agus Supriono**
}

\begin{abstract}
This paper examines the conversion of Indonesia's natural forests to timber and tree crop plantations, notably oil palm. The principal aims are to understand the impact of this process on natural forest and on forest-dwelling people, and to establish whether past and present policies governing this process are meeting their objectives. Among the key findings of the study are that: (1) timber plantation development policies legitimate the degradation of natural forests; (2) subsidies are ultimately unnecessary for the development of timber plantations; (3) tree crop plantation developers request more land than they need to get added profits from the timber on lands to be cleared; (4) overlapping and chaotic forest land use classification systems work to the benefit of private plantation developers at the expense of the rights and livelihoods of forest-dwelling people; and (5) resolution of these problems is hampered by the persistence of the government's top-down approach and nonrecognition of traditional land use rights. We recommend that the remaining natural forests on conversion forest lands be reclassified as permanent forests, that plantation development take place only on unproductive production forest lands, and that forest land use redistribution be devolved to the local level.
\end{abstract}

\section{Introduction}

The development of large-scale timber and tree crop plantations have different backgrounds. The increasing area of unproductive production forest and various attractive incentives from government to the private sector encouraged the former. The latter, oil palm in particular, was driven more by the high demand of the export market. Government policies on forest conversion and land designation plus various investment incentives are responsible for boosting the development of this sector.

Since the end of the 1970s, Indonesia has been relying on its natural forests to support national economic development, and forest concession rights ( Hak Pengusahaan Hutan - HPH) have been the dominant system to utilize natural forests and their resources. The Agreed Functional Forest Classification (Tata Guna Hutan Kesepakatan - TGHK) and the Provincial Land Use Planning (Rencana Tata Ruang Wilayah Propinsi RTRWP) ${ }^{1}$ are the bases for design and control in the development of HPHs, timber plantation concessions (Hutan Tanaman Industri - HTI) and tree crop plantations, particularly large-scale ones, so as to minimize the negative impact on the environment by reducing the conversion of natural forest.

In reality, however, HPH operations have been one of the main causes of natural forest degradation. The rate of this degradation has significantly increased in the 1990s. The government invited private sector involvement in the development of timber plantations by giving various incentives. Oil palm plantations have also led to natural forest cover loss because they are established primarily on conversion forest lands. The integration between TGHK and RTRWP in a "top-down" manner has not solved this problem, and has led to negative social and economic impacts.

The development of timber and tree crop plantations has been made possible because, according to the TGHK and RTRWP, there is still land available. The government has designated production forest lands (on the basis of the TGHK) that are unproductive as sites for the development of timber plantations. For tree crop plantations, the government has allocated land that is outside of the forest domain (on the basis of the TGHK classification) or on nonforest land (on the basis of the RTRWP classification). However, these lands classified as being outside the forest domain or on nonforest land may actually have forest cover.

\footnotetext{
* Lecturer at the Forestry Faculty, Bogor Agricultural University, Bogor. E-mail: hariadi@indo.net.id

** Researcher at the Indonesia Association for Estate Crops Research, Bogor.
} 
In reality, however, the guidance provided under the TGHK and RTRWP cannot be used as a reliable reference. Some of the reasons are first, de facto, the integration of these two approaches cannot resolve local community claims to forest land. Second, there has been too much intervention from the central government concerning the use of forest land. Consequently, problems related to land use were inevitable in the development of tree crop plantations and timber plantations.

This paper looks mainly at how far these institutional and socio-political issues have influenced policy formulation and the implementation of timber and tree crop plantations. Data and information presented in this paper are taken from official sources, mass media, selected references, interviews, and the authors' experience in the field.

There are four sections in this paper. The first section provides information on the development of large-scale timber and tree crop plantations. Section two discusses the process of natural forest conversion by HPHs, HTIs and tree crop plantations. The third section analyses timber and tree crop plantation policy. The concluding section presents a summary of the findings and recommendations on changes that should be made.

\section{Timber and tree crop plantations}

\section{Timber plantations}

Timber plantations are developed either independently of, or in association with, existing HPHs. Independentlymanaged timber plantations may be either for HTI Pulp and HTI non-pulp (wood construction) purposes. The management of timber plantations associated with HPHs involves a transmigrant labor force. This kind of management is called HTI-Transmigrasi and generally produces trees for non-pulp purposes.

The land area allocated for HTI is 4.7 million ha (MOF 1997), and up to October 1998 the government had approved the use of 4.6 million ha of this area. The distribution of HTIs by type, number of units, and land area is shown in Table 1.

Through October 1998, 2 million ha had been planted, or $45 \%$ of the total HTI approved by the government (see Tabel 1). Of the total area allocated for HTI, the highest proportion is for pulp (68\%), followed by HTI for non-pulp purposes (18\%), and HTI-Transmigrasi (14\%). The growth of HTI-Transmigrasi has been limited by the availability of new land for transmigration purposes. However, demand for this land will continue to increase as the land area targeted for this purpose increases, particularly in eastern Indonesia. Of the funds from the Reforestation Fund (Dana Reboisasi - DR) allocated to timber plantation development, HTI for pulp will absorb almost $40 \%$ whereas HTI non-pulp will only take $8 \%$.

Out of the 98 HTI units that have been approved, 24 units are owned by 17 companies with a total area of 3,370,000 ha, or $73 \%$ of the total HTI area approved (MOFEC 1998a). The rapid development of HTIs has been encouraged by the provision of financial assistance for timber plantations using the Reforestation Fund (DR).

There are, however, 22 HTI units (four HTI pulp units and 18 HTI non-pulp units) that have been established without the assistance of the reforestation fund. One of the HTI company directors interviewed stated that companies receiving a subsidy from the Reforestation Fund must involve a state-owned company in their corporate management, which in turn increases

Table 1. Recapitulation of HTI development until October 1998 (Ministry of Forestry and Estate Crops, 1998).

\begin{tabular}{|c|c|c|c|c|c|}
\hline \multirow[t]{2}{*}{ No } & \multirow[t]{2}{*}{ Type } & Applications & $\begin{array}{c}\text { Approved } \\
\text { applications }\end{array}$ & Approved area & Planted Area \\
\hline & & \multicolumn{2}{|c|}{ (Units) } & \multicolumn{2}{|c|}{ (ha) } \\
\hline \multirow[t]{5}{*}{1} & HTI Pulp (23 units ) & 23 & 18 & $3,128,443$ & 997,213 \\
\hline & - Priority & 13 & 13 & $2,605,938$ & 395,908 \\
\hline & - with DR & 9 & 9 & $1,799,162$ & na \\
\hline & - without DR & 4 & 4 & 806,776 & na \\
\hline & - Non Priority & 10 & 5 & 522,505 & 601,305 \\
\hline \multirow[t]{3}{*}{2} & HTI non-pulp (52 units) & 52 & 31 & 835,334 & 812,399 \\
\hline & - $\quad$ with DR & 17 & 13 & 377,613 & na \\
\hline & - without DR & 35 & 18 & 457,721 & na \\
\hline 3 & HTI-Transmigration (70 units) & 70 & 49 & 640,441 & 266,007 \\
\hline \multicolumn{2}{|c|}{ TOTAL } & 145 & 98 & $4,604,218$ & $2,075,619$ \\
\hline
\end{tabular}

$\mathrm{DR}=$ the reforestation fund; Priority = prioritized by the government as HTI Pulp; na = not available. 
management costs for the recipient company, particularly for the administrative costs to cash the contribution from the reforestation fund. Companies that are not willing to receive this subsidy usually already have a secure market for the timber from their HTIs, either to supply their existing timber processing factories or for export.

\section{Tree crop plantations}

The area of tree crop plantations in Indonesia, both large- and smallscale, has tended to increase from year to year. Among the main plantation commodities (rubber, coffee, tea, coconut, cacao, sugarcane and oil palm), the largest area is planted to rubber and oil palm. The area of oil palm plantations has seen a spectacular increase in the last ten years, with an average annual rate of growth of $14 \%$, far higher than the $2 \%$ annual growth rate of rubber plantations (Susila 1998). In 1986 , the oil palm plantation area was about 606,800 ha, and in 1997 it increased to 2.25 million ha. The main oil palm plantations areas are in the provinces of North Sumatra (905,000 ha), Riau (544,700 ha), West Kalimantan (211,400 ha) and South Sumatra (206,000 ha). Further rapid development is expected to occur in East Kalimantan, Sulawesi and Irian Jaya (Susila 1998).

The total area of oil palm plantations is still smaller than that of rubber (about 3,5 million ha in 1997). It is interesting, however, that the structure of ownership of the former is the inverse of the latter. Whereas rubber plantations are dominated by smallholders (83\%), large scale enterprises (both state and private) dominate 66\% of oil palm plantations (Susila 1998).

The area of oil palm plantations grew relatively rapidly in the period 1978-1997 (see Figure 1), with a high annual increase in area of $21.7 \%$ for privately-owned plantations, and a rate of $2.9 \%$ for state-owned plantations and $19.3 \%$ for smallholder plantations (Susila 1998). The most common method for the establishment of plantations is through the conversion of forest land, since the procedure of land acquisition is relatively easy and the marketing of timber cut from the forest is profitable. Thus it can be said that many of the existing oil palm plantation areas result from the conversion of production forest.

The annual growth rate in the area of smallholder rubber plantations was only $2.2 \%$ in the period $1986-1996$, and that of coffee plantations was $2.34 \%$ in the same period. Besides having a low rate of growth, smallholder plantations in general have not been established on production forest lands. Farmers usually use critical degraded lands ${ }^{2}$ or secondary forests, or replant on abandoned plantations. Smallholder rubber has been produced mainly in Sumatra and Kalimantan, whereas coffee has mainly been cultivated in Lampung, South Sumatra and South Sulawesi. The development of oil palm, rubber and coffee in Indonesia (1987-1997) is shown in Figure 2.

Figure 2. The production rate of oil palm, rubber and coffee in Indonesia (1987-1997).

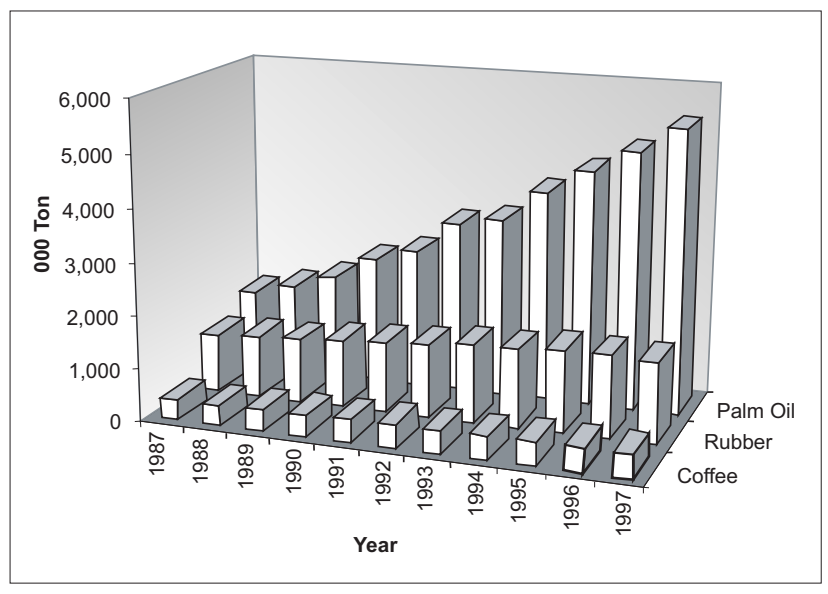

The expansion of the oil palm sector has been rapid but this growth has greatly slowed beginning in mid-1998. Among the reasons for this slowed growth was a high export tax, reduced foreign investment resulting from political instability, and fears of a supply glut. Among the factors that promoted growth prior to mid-1998 were the following. With a productivity level of fresh fruit bunches (tandan buah segar-TBS) of 18-21 ton/ha/year, investment in oil palm had an internal rate of return (IRR) as high as $24-43 \%$. The prospect of crude palm oil (CPO) was bright. For domestic consumption alone, it was estimated that the 
demand for CPO would increase at the rate of $8-10 \%$ annually for the period $1995-2000$ and 5-7\% annually for the period 2000-2005 (Arifin and Susila 1998). It was predicted the world level consumption of CPO would increase about 5\% annually for the period of 1995-2000 and it was projected that in 2000 the consumption level would reach 18.2 million ton, although the price was projected to decline to US\$ 415/ton in 2000 (Susila 1997).

In early 1998 there were 50 foreign companies involved in the oil palm sector with total investments valued at US $\$ 3$ billion. The total area planned for new plantations was 926,650 ha in Sumatra, Kalimantan, Sulawesi, and Irian Jaya. ${ }^{3}$ The government decided that Riau and North Sumatra would be closed to new investment in oil palm plantations. ${ }^{4}$ Foreign investors interested in oil palm development have been mainly from Malaysia. One of the reasons for their interest is that land availability for this kind of development is very limited in their own country, and Indonesia is the closest area to their processing facilities in Malaysia.

Other foreign investors, for example those from England and Singapore, have had a keen interest in state-owned plantations that perform well. The Indonesian government intends to privatize some of its state-owned plantations by selling a portion of their shares to the private sector, both to national and international companies. However, the government is trying not to sell all of its shares so that foreign companies will not become the majority shareholders. Also, what the plantations need in involving foreign companies is to develop derivative products and to build international marketing networks. ${ }^{5}$

For domestic investors, the interest in oil palm development is not limited to companies that already have experience in plantation management. Their interest extends to companies involved in timber production, such as the stateowned forestry companies. PT INHUTANI III, ${ }^{6}$ for example, has planned to develop 500 ha to 1,000 ha of oil palm plantations annually. ${ }^{7}$ At the same time PT Inhutani I will also enter the plantation business, with particular attention to rubber and oil palm. ${ }^{8}$ By the end of February 1998, the Minister of Forestry and Estate Crops had officially permitted Perum Perhutani and PT INHUTANI I to $\mathrm{V}$ to expand their activities to the plantation activities such as oil palm. One of the main reasons for this change is that the timber industry is a long-term investment, whereas tree crops plantations are a short-term investment, which can be expected to help improve the cash flow in the state companies. ${ }^{9}$

Many Indonesian companies that have little experience in plantation management are also trying to get involved in the oil palm plantation business. In general, they want to take advantage of a special credit scheme for the development — through partnership — of smallholder plantations [for example the Pola Perusahaan Inti Rakyat-Transmigrasi (PIR-Trans), Kredit Koperasi Primer untuk Anggota (KKPA)]. Although large companies are obliged to participate in this partnership by giving technical assistance to farmers, their involvement also provides an opportunity for them to: (1) be contractors for the plantation development owned by farmers, (2) sell the timber produced through land clearing activities, and (3) get a special fee to assist farmers in getting access to this credit. Various people have mentioned that through such a working arrangement, the large enterprises are not helping the farmers, but instead they are taking advantage of the farmer credit scheme. ${ }^{10}$

Although growth of the oil palm sector has slowed greatly, there are preliminary indications that growth may resume (Casson 1999). It has been projected that the oil palm plantation area in Indonesia would reach 2.97 million ha in 2000. By 1997, the agreed area of production forest to be used for plantations had reached 6.7 million ha. This figure does not include the proposed 9 million ha for further tree crop plantation development (MOFEC 1998a).

\section{Natural forest conversion}

The area of state-owned forest ${ }^{11}$ has changed significantly since the integration of the TGHK and RTRWP. Comparison of state-owned forest area between 1984 and 1997 indicates that, at the national level, the protection forest area has increased from 29.3 million ha to 34.6 million ha. The area of conservation forest remains the same, but the production forest area has been reduced from 64 million ha to 58.6 million ha. Meanwhile the area of conversion forest, used for such purposes as tree crop plantations, transmigration, etc., has experienced a reduction from 30 million ha in 1984 to 8.4 million ha in 1997.

By June 1998, out of the above-mentioned total area of production and conversion forests, 69.4 million ha have been allocated for HPH; 4.7 million ha ${ }^{12}$ have been reserved for HTI, and 3 million ha for large-scale plantation development. According to Government Regulation No 21 of $1970^{13}$ and No. 7 of 1990, HPH and HTI development must take place within production forest areas with a permanent forest status, whereas tree crop plantations must be established within conversion forest areas.

According to calculations made on the basis of various feasibility studies, on average $22 \%$ of the total area managed as HTI was productive natural forest prior to its establishment, even though the land was supposedy 
unforested. ${ }^{14}$ This means that as of June 1998, 1 million ha $(22 \% \times 4.7$ million ha) of natural forest has been converted to timber plantations.

Meanwhile, several protection and conservation forest areas (where change of function is not permitted) have been encroached upon by plantation activities, by timber plantations, and also by shifting cultivation. Overall changes in forest area and forest functions in Indonesia from 1984 to 1997 are shown in Table 2.

\section{Natural forest degradation by HPHs}

Data from the Ministry of Forestry and Estate Crops ${ }^{15}$ show that as of June 1998, 69.4 million ha of forest area had been allocated to 651 HPHs. Of this total area 34 million ha (49\%) are managed by $291 \mathrm{HPH}$ in their first term of operation (first 20-year) and 35.5 million ha (51\%) is managed by the 359 other $\mathrm{HPH}$, whose first term concession rights have expired.
These data and detailed break down at the bottom of Figure 3 indicate that by June 1998, forest degradation resulting from $\mathrm{HPH}$ operations had reached 16.57 million ha. This area will be rehabilitated, changed to a different land use categories, and reserved for other uses. Changes in $\mathrm{HPH}$ status and forest functions under $\mathrm{HPH}$ management are shown in Figure 3.

In connection with these changes in forest function, PT INHUTANI I has been seeking partnerships with the private sector to establish oil palm plantations on concession lands whose rights have been revoked and transferred to PT INHUTANI I. As of March 1998, PT INHUTANI I had found five partners, all of which were located in eastern Indonesia. Four of these partnerships are with PT Texaco in Maluku (60,000 ha). The rest are with PT Gmelina Lestari, PT. Surya Dumai Group and PT Komismar Maju Agro but the extent of each operation is not yet known. ${ }^{16}$

Table 2. Changes in state-owned forest area and forest function in Indonesia (1984-1997).

\begin{tabular}{|c|c|c|}
\hline $\begin{array}{l}\text { Land-Use Category of State- } \\
\text { Owned Forest Land }\end{array}$ & $\begin{array}{l}\text { Permitted Changes in } \\
\text { Forest Function }\end{array}$ & Changes in Forest Functions Already Took Place \\
\hline $\begin{array}{l}\text { Protection Forest } \\
1984=29.3 \text { million ha } \\
1997=34.6 \text { million ha }\end{array}$ & $\begin{array}{l}\text { [Function not permitted to } \\
\text { be changed] }\end{array}$ & $\begin{array}{l}\text { After the integration of the TGHK and RTRWP in } 1997 \text {, } \\
\text { the total area of protection forest increased to } 34.6 \\
\text { million ha. Based on the evaluation of the HPH area, } \\
\text { the area of protection and conservation forests has } \\
\text { increased by } 1.31 \text { million ha (see Figure } 4 \text {, in changes } \\
\text { in function of HPH area). } \\
\text { Encroachment occurred but data are not available. }\end{array}$ \\
\hline $\begin{array}{l}\text { Conservation Forest (Nature } \\
\text { Reserves, National Parks, etc.) } \\
1984=1997=19 \text { million ha }\end{array}$ & $\begin{array}{l}\text { [Function not permitted to } \\
\text { be changed] }\end{array}$ & - Encroachment occurred but data are not available. \\
\hline $\begin{array}{l}\text { Production Forest } \\
1984=64 \text { million ha; } 1997= \\
58.6 \text { million ha } \\
\text { Consisting of : } \\
\text { - Permanent production forest } \\
1984=1997=34 \text { million ha } \\
- \text { Limited production forest }{ }^{a} \\
1984=30 \text { million ha } \\
1997=24.6 \text { million ha }\end{array}$ & $\begin{array}{l}\text { - } 69.4 \text { million ha }{ }^{\mathrm{b}} \text { is } \\
4.7 \text { million ha is } \\
\text { planned for timber } \\
\text { plantations } \\
\text { development of tree } \\
\text { crop plantations is } \\
\text { allowed within timber } \\
\text { plantation area }\end{array}$ & $\begin{array}{l}\text { Forests as yet unlogged by HPH: } 9.4 \text { million ha within } \\
\text { the permanent production forest, } 12.3 \text { million ha within } \\
\text { limited production forest. Degraded forest within HPH } \\
\text { area: } 16.57 \text { million ha }{ }^{\mathrm{c}} \text {. } \\
\text { - As of June } 1998,4.6 \text { million ha has been allocated to } \\
\text { HTIs. These timber plantations will likely convert about } \\
1 \text { million ha primary natural forest. } \\
\text { - As of March } 1998,60.000 \text { ha of tree crop plantations } \\
\text { operated within the production forest area. }\end{array}$ \\
\hline $\begin{array}{l}\text { Conversion Forest } \\
1984=30 \text { million ha } \\
1997=8.4 \text { million ha }\end{array}$ & $\begin{array}{l}\text { - Function is changed } \\
\text { altogether } \\
\text { In 1997, } 8.4 \text { million ha } \\
\text { remains as conversion } \\
\text { forest, in the form of } \\
\text { natural forest. }\end{array}$ & $\begin{array}{l}\text { - Total area for tree crops plantation as of June 1998: } \\
\text { - Group (holding company) } \sim 2.8 \text { million ha } \\
\text { - Non Group (individual companies) } \sim 3.9 \text { million ha } \\
\text { - } \quad \text { Total (Group and Non Group) } \sim 6.7 \text { million ha } \\
\text { - Estimated deficit/surplus if all tree crop plantations are } \\
\text { in operation as shown in Table } 3 \text {. }\end{array}$ \\
\hline
\end{tabular}

a Limited production forest are located in steeper slopes compared to the permanent production forest, as a result the number of trees allowed to be cut is lower in the former. In the Indonesian selective cutting system, the minimum diameter of trees to be cut is $60 \mathrm{~cm}$ whereas in the permanent production forest the diameter limit is $50 \mathrm{~cm}$.

b Forest areas managed under HPH may include conversion forest.

c From degraded forest resulting from $\mathrm{HPH}$ operation, 9.54 million ha will be rehabilitated, and 5.12 million ha allocated and reserved for indefinite uses, 0.71 million ha will be changed into different functions, and 80,000 ha for transmigration purpose. 
Figure 3. Changes in HPH status and forest area functions previously managed by HPHs through June 1998 (Data modified from the Ministry of Forestry and Estate Crops, 1998).

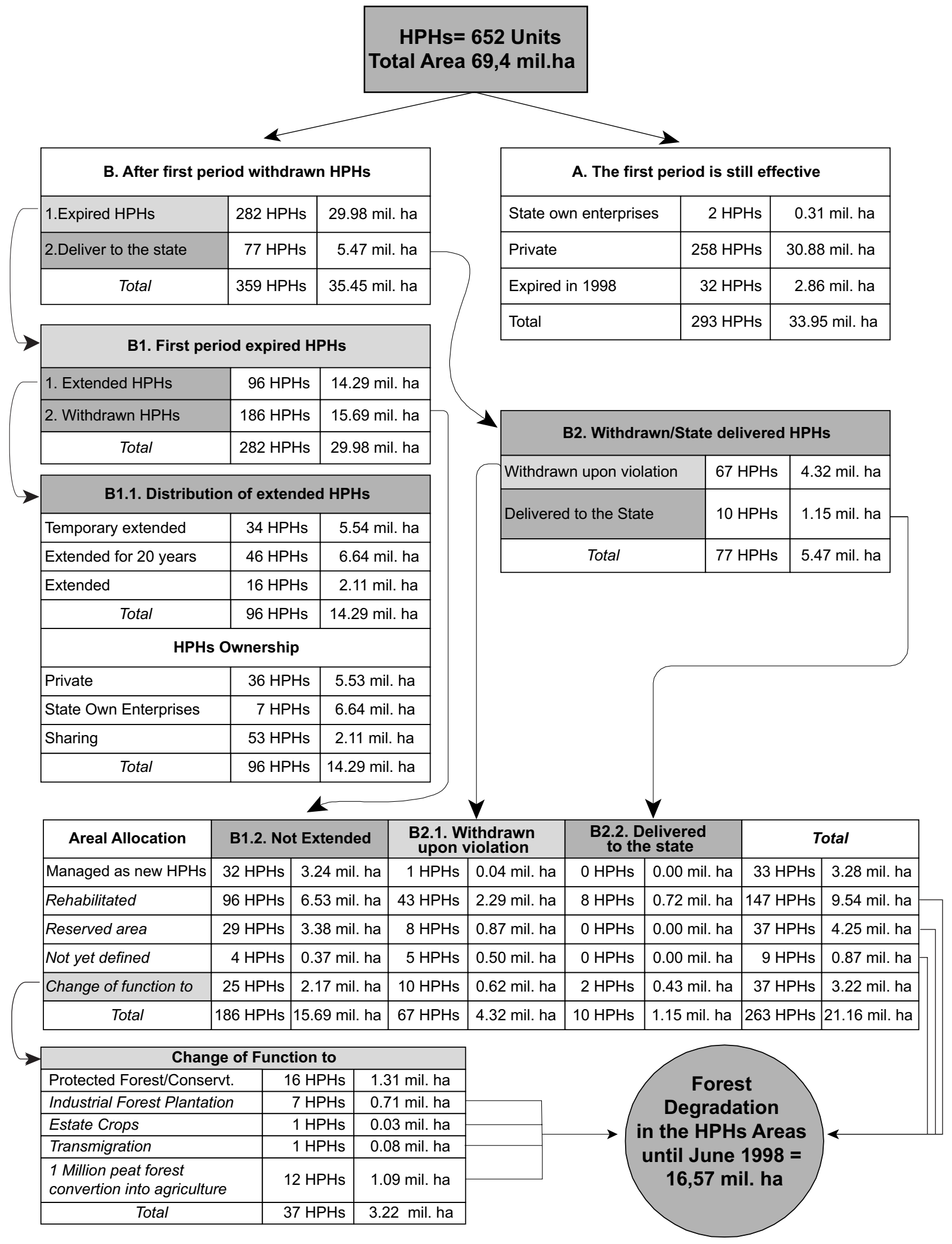




\section{Allocation of conversion forest}

The area of conversion forest has been decreasing, and by the end of 1997 it had reached 8.4 million ha. Tree crop plantations that will be developed in this conversion forest area and that have been approved so far amount to 6.8 million ha. ${ }^{17}$ Of this approved area, 938,763 ha (DGEC, 1998) will be developed under the small-holder plantation programme (PIR). This approved plan does not include other proposed plantation development, which as of June 1998 required a further 9 million ha. ${ }^{18}$ If all of these proposed plantations are agreed to, and without taking into account those in the proposal stage, there is a deficit of conversion forest land available in the Sumatra and Kalimantan. The same problem will be faced if the 9 million ha proposal (proposed mainly for eastern Indonesia) is finally agreed to and implemented. The total area of conversion forest in Maluku and Irian Jaya available is only 4.6 million ha. These facts show how high the threat of conversion is in supposedly permanent forests.

Changes in the area of conversion forest from 1981 to 1997, and the potential surplus/deficit of this land if all proposals to develop tree crop plantations are granted, are presented in Table 3.

\section{Encroachment of conservation and protection forests}

The area of timber and tree crop plantation development often overlaps with conservation areas. For example, the existence of Bukit Tigapuluh National Park (127,698 ha)

Table 3. Changes in area of conversion forest (1981-1997) and the Surplus/Deficit of land if all proposals are agreed toand in operation

\begin{tabular}{|c|c|c|c|c|c|c|c|c|c|c|}
\hline \multirow{3}{*}{$\begin{array}{l}\text { Province/ } \\
\text { Region }\end{array}$} & \multirow{2}{*}{\multicolumn{4}{|c|}{$\begin{array}{l}\text { Changes in area of conversion } \\
\text { forest }^{\mathrm{a}}(1,000 \mathrm{ha})\end{array}$}} & \multicolumn{4}{|c|}{ Large scale plantation companies $(1.000 \mathrm{ha})^{\mathrm{b}}$} & \multirow{3}{*}{ Total } & \multirow{3}{*}{$\begin{array}{l}\text { +/- Forest } \\
\text { Converted } \\
(1,000 \text { ha }\end{array}$} \\
\hline & & & & & \multicolumn{2}{|c|}{ Non-Group } & \multicolumn{2}{|c|}{ Group $^{c}$} & & \\
\hline & 1981 & 1984 & 1990 & 1997 & Approved & Released & Approved & Released & & \\
\hline DI. Aceh & 188 & 193 & 848 & 95 & 136.35 & 120.62 & 5.78 & 6.46 & 269.21 & -174 \\
\hline North Sumatra & 532 & 254 & 254 & 37 & 65.40 & 46.90 & 56.61 & 26.24 & 195.15 & -158 \\
\hline West Sumatra & 597 & 438 & 438 & 189 & 56.53 & 60.60 & - & - & 117.12 & 72 \\
\hline Riau & 2773 & 1754 & $\left({ }^{*}\right)$ & 335 & 837.84 & 717.28 & 719.94 & 330.02 & 2605.07 & -2270 \\
\hline Jambi & - & 1013 & 727 & - & 105.81 & 98.48 & 136.51 & 124.22 & 465.02 & -465 \\
\hline South Sumatra & 2421 & 1186 & 1186 & 774 & 123.24 & 17.77 & 11.50 & 11.51 & 164.03 & 610 \\
\hline Bengkulu & 23 & 194 & 179 & 120 & - & - & - & - & - & 120 \\
\hline Lampung & 573 & - & 153 & 137 & 68.20 & 74.78 & 57.69 & 64.27 & 264.94 & -128 \\
\hline Sumatra & 7107 & 5032 & 3785 & 1687 & 1393.35 & 1136.43 & 988.03 & 562.72 & 4080.53 & -2394 \\
\hline Bali & 4 & - & $\left({ }^{*}\right)$ & $\left(^{*}\right)$ & - & - & - & - & - & - \\
\hline West NT & 224 & 196 & $\left({ }^{*}\right)$ & $\left({ }^{*}\right)$ & - & - & - & - & - & - \\
\hline East NT & 278 & 2802 & 181 & 181 & - & - & - & - & - & 181 \\
\hline East Timor & 45 & 10 & 10 & - & - & - & - & - & - & - \\
\hline $\begin{array}{l}\text { Bali, NTT and } \\
\text { East Timor }\end{array}$ & 551 & 3008 & 191 & 181 & - & - & - & - & - & 181 \\
\hline West Kalimantan & 1323 & 1509 & 1509 & 534 & 94.76 & 58.84 & 49.40 & 24.60 & 227.60 & 306 \\
\hline Central Kalimantan & 6068 & 3000 & $\left({ }^{*}\right)$ & $\left(^{*}\right)$ & 267.37 & 267.99 & 159.36 & 82.46 & 777.18 & -777 \\
\hline South Kalimantan & 1331 & 285 & 285 & 265 & - & - & 126.18 & 101.68 & 227.86 & 37 \\
\hline East Kalimantan & 5513 & 3500 & $\left({ }^{*}\right)$ & $\left({ }^{*}\right)$ & 309.60 & 207.01 & 254.39 & 52.68 & 823.67 & -824 \\
\hline Kalimantan & 14235 & 8294 & 1794 & 799 & 671.73 & 533.83 & 589.32 & 261.42 & 2056.30 & -1257 \\
\hline North Sulawesi & 304 & 699 & 294 & 35 & 8.00 & 0.59 & - & - & 8.59 & 26 \\
\hline Central Sulawesi & 1028 & 335 & 242 & 269 & 76.57 & 61.33 & 59.95 & 19.12 & 216.97 & 52 \\
\hline South Sulawesi & 165 & 259 & 259 & 259 & 41.40 & 15.70 & 30.35 & 40.77 & 128.22 & 131 \\
\hline South East Sulawesi & 669 & 699 & 699 & 212 & 13.12 & - & - & - & 13.12 & 199 \\
\hline Sulawesi & 2166 & 1992 & 1494 & 775 & 139.09 & 77.62 & 90.30 & 59.89 & 366.89 & 408 \\
\hline Maluku & 1030 & 436 & $(*)$ & 2305 & - & - & - & - & - & 2305 \\
\hline Irian Jaya & 7123 & 11775 & 11775 & 2671 & 11.19 & 3.28 & 257.81 & 20.51 & 292.78 & 2378 \\
\hline INDONESIA & 33635 & 30537 & 19039 & 8418 & 2215.35 & 1751.16 & 1925.46 & 904.53 & 6796.50 & 1621 \\
\hline
\end{tabular}

(a). Data adapted from the Central Bureau of Statistics (various years); (b) Ministry of Forestry and Estate Crops (1998); (c).Non-Grup plantations are plantation companies which do not have holding company; Group plantations are plantation companies which possess holding companies; $\left(^{*}\right)$ in these provinces the location of production forest that may be converted to other uses is still not clearly separated. 
which extends between the Jambi and Riau Provinces, has been threatened by the two large-scale plantations PT Sumatra Makmur Lestari (8,000 ha) and PT Arvena Sepakat $(5,450 \mathrm{ha}) .{ }^{19}$ The same situation applies with regard to the Inti Rakyat Blambangan plantation, in Umpu Lampung, which encroaches on 216 ha of protection forest nearby (DGEC 1998). In East Kalimantan there are 21 cases of tree crop plantations operating in protection forest area (Sunderlin 1998).

\section{Analysis of timber and tree crop plantation policies}

\section{Timber extraction from conversion forests}

Government policies on land allocation and natural forest conversion have induced the private sector to invest their capital in timber and tree crop plantations. One holding company may operate and own several HPHs, HTIs and tree crop plantations at the same time. Based on various reports, some holding companies such as the Raja Garuda Mas, Astra, Kalimanis, Salim, Sinar Mas, Uniseraya, Texmaco, and Barito Pacific Groups, are involved in HPHs, HTIs and tree crop plantations. ${ }^{20}$

This diversification of investment has also been accompanied by deviations. For example, after acquiring land allocated for plantations and clearing the timber on it, some companies delay or even cancel their operations. These deviations are illustrated by the following information:

1. Evaluation of timber plantations up until January 1996 indicated that, compared to the initial plans, planting realization occurred only at the rate of $46 \%$ for HTI pulp and 13\% for HTI non-pulp (MOF 1996). At the end of eight years in operation, HTIs were expected by the government to supply raw materials for the pulp industry, which otherwise would have been taken from natural forests. In reality, however, between 1990 and July 1997, the overall realization of planting activity has only reached $23.1 \%$ of the total area planned. $^{21}$ This has caused the timber and pulp industries to rely heavily on natural forest as their source of raw material. As a consequence, illegal cutting of natural forest has been on the increase.

2. The Head of Bengkulu Provincial Investment Board has said that the location permits of as many as ten tree crop plantation companies in Bengkulu will be revoked. This is because these investors have not managed the land allocated to them. Of these ten companies, seven (61,000 ha) are located in the South Bengkulu District, one in North Bengkulu District
( $3,150 \mathrm{ha})$, and two $(2,350 \mathrm{ha})^{22}$ in Rejanglebong District.

3. An official from the Provincial Office of Tree Crop Plantations in Riau Province stated that forest clearance permits obtained by tens of tree crop plantation companies who then abandoned their land will be revoked and transferred to other companies. ${ }^{23}$

4. The Government of East Kalimantan will revoke 50 out of the 105 location permits for tree crop plantation investors who intend to establish their projects in this province. This threat was issued because many investors are only interested in reaping benefits from the permit, without seriously intending to establish a plantation. In early 1998 this same government revoked 93 location permits. The actions of these companies have damaged the interests of local development. It is not only that the timber in the forests was depleted, but also that their conduct foreclosed the opportunities of developers who are more serious and who might have been interested in doing business in East Kalimantan. ${ }^{24}$

The policy of integrating timber plantation and tree crop plantation development by state-owned companies within production forest areas has had some negative impacts. In addition to improving these companies' performance, the government's reason for involving them in plantation development has been as a strategic measure to safeguard the forest. These measures, however, have always been at the expense of the natural forest. Thus these companies' motivation in developing oil palm plantations is the same as that of the private sector, namely to get double economic benefits from the oil palm plantation and also from the sale of timber cut from the natural forest during the forest clearing stage.

\section{Agrarian disputes and their social impact}

Although feasibility studies are required in the planning process of timber and tree crop plantations, the guidance provided in the TGHK and RTRWP and in their integrated form has so far been unable to resolve land dispute problems.

Tree crop plantations in South Sumatra, for example, have displaced smallholder farmers from their land. At least 41,155 ha of smallholder plantation lands owned by 4,101 households in the eight districts in South Sumatra Province have been forcibly taken over by 13 tree crop plantation companies. The 13 companies are PT Barito Pacific Timber, PT Pakerin, PTPN VII, PT Mitra Ogan, PT Gunung Sawit Bina Lestari, PT London Sumatra, CV 
Harvelia, PT Bumi Arjo Makmur, PT Perjapin Prima, PT Tata Hamparan Eka Persada, PT Cipta Futura Plantation, PT Multradin Multi Maju, and PT Surya Bumi Agro Langgeng. ${ }^{25}$

Also in South Sumatra Province, all 81 of the oil palm plantation companies, with a total allocated area of 554,000 ha, have had land dispute problems with local communities. The land under dispute accounts for 83,000 ha or $11 \%$ of the total area oil palm plantations. The same difficulties have been observed in the case of 14 timber plantation companies in the province. ${ }^{26}$ Thus in total the South Sumatra government has faced a total of 103 land dispute cases resulting from timber and tree crop plantation development.

In the era of economic crisis and political instability, antiHPH, HTI and tree crop plantation movements have been emerging. In several places, destruction and theft of forest and plantation products have been occurring. The following are examples of such occurrences.

1. Farmers occupied a HTI area owned by PT Dharma Hutan Lestari in Gedongwani, Tanjungbintang, South Lampung. Thousands of farmers cut trees, piled them at several locations on road sides and then sold them. ${ }^{27}$

2. Land belonging to PTPN II in North Sumatra was intentionally fallowed and was to be planted with tobacco in 1999, 2000 and 2001. However, the local community started to cultivate this land in 1998 and has been accused of stealing fresh oil palm fruit, cacao and sugar cane from PTPN II. ${ }^{28}$ It is estimated that 200 ha of oil palm plantation owned by PT Raya Padang Langkat, Besitang subdistrict, Langkat District, North Sumatra has been affected by this incident. $^{29}$

3. At PTPN IV Sumatra, from January to June 1998, there were 5,793 cases of theft involving 6,480 tons of oil palm fruit and 450 cases involving 30.5 tons of cacao. ${ }^{30}$ According to the head of the Cooperative Agency of Plantation Enterprises in Sumatra, worsening security in the plantation business has created an unpleasant environment both for plantation workers and their managers. ${ }^{31}$ This situation has forced the security apparatus to mobilize 900 security personnel to guard tree crop plantations in North Sumatra.

4. Looting has affected not only large-scale but also small-scale tree crop plantations. For example, coffee and pepper farmers in Lampung have suffered not only from looting of their crops, but also their money from the sale of the produce has become the target of robbery. In Lampung, eight cases of robbery involving hundreds of million rupiah occurred between July to August 1998. ${ }^{32}$

\section{Controversies in timber plantation policy}

After years of implementation of the HPH system, the government has been faced with two conditions. First, many HPH operations lost their concession rights because their forests were badly damaged, and future management of these forests has been transferred to a state-owned forestry company. For this reason, the government has had to implement new mechanisms for natural forest rehabilitation. Second, the foreign exchange earnings from processed timber exports, plywood in particular, and the absorption of the labour force in HPH operations and the timber industry have to be maintained.

Facing these conditions, tree plantations are regarded as a good solution to increase natural forest productivity. ${ }^{33}$ For this reason the government provides various incentives for tree plantation development, such as subsidies through the Reforestation Fund, which have been well responded to by the private sector. There has been, however, an oversupply of timber from natural forest - some of it cut illegally which has caused the price of HTI-produced timber to be very low. ${ }^{34}$ Consequently, HTIs have never been regarded as financially feasible as independent and selfsufficient enterprises. For this reason caculations of the financial appropriateness of HTIs have always been done in association with the timber processing industries to which they are connected. ${ }^{35}$

Private companies have abused the incentives provided for timber plantation development by limiting themselves to harvesting the natural timber at the HTI site and by using the subsidy from the Reforestation Fund. Facing this reality, the government needs to revise the production system in natural forest management $(\mathrm{HPH})$, since this has been the main cause of natural forest degradation. This has not been achieved because the government needs to maintain the HPH system as one of the sources of state revenue. From the government point of view, timber plantation policy has been regarded as a compromise solution to this problem. ${ }^{36}$ Degraded natural forest within the HPH area is no longer considered part of the HPH, but rather as part of the future timber plantation area. Thus, even when the forest within its area is degraded, the performance of the HPH seems unaffected. With this policy, the production system of natural forest (HPH) is maintained, because the degradation of natural forest is not taken into account. Timber plantation policy therefore implicitly legitimates the degradation of natural forests by HPH operations. This scenario of timber plantation development would not have come into being if HPHs 
had managed their natural forests properly. It is not surprising, therefore, that timber plantation development policy - of which the subsidy scheme was designed by a study funded through the Asia Development Bank - has been supported by the private sector.

In the view of the government, the inclusion of the Reforestation Fund in the state budget revenue (APBN), as requested by the IMF, hampers timber plantation development because the high interest rates (no lower than $12 \%$ ) will make the timber plantations financially unfeasible (MOFEC 1998b). Nevertheless, there are 22 companies managing 1.2 million ha of HTI that have not taken advantage of the subsidy from the reforestation fund. The director of one of these companies (who was not willing to be named) stated that receiving subsidies from the Reforestation Fund requires inclusion of stateowned companies in corporate management, which in turn increases management costs and other costs related to cashing supplied funds. Companies that are not willing to receive this subsidy usually already have secure markets for the timber from their plantations, especially for the export market.

This shows that for certain companies, the provision of a subsidy for timber plantations has no real benefit because the transaction $\operatorname{costs}^{37}$ to obtain it are higher than the actual amount of subsidy received. In this case, the inclusion of the Reforestation Fund in the state budget, which eliminates low interest loans from the Fund, does not actually hinder the development of timber plantations, as suggested by the government. This is because the actual hindrance is not the interest rate for the loan, but rather the high transaction costs.

\section{Forest land use policy}

Another important issue in the development of timber and tree crop plantations is the inadequacy of TGKH and RTRWP to resolve land use conflicts. This has become a major issue faced by HPHs, HTIs, and tree crop plantations. ${ }^{38}$ As discussed earlier, this land use issue has triggered some social conflict. Although its area is relatively small compared to that of HPHs and HTIs, tree crop plantations, and especially oil palm plantations, have had a greater social impact.

This structural issue cannot be resolved if the government continues to apply a top down planning approach. The integration of TGHK and RTRWP has clearly been on paper only; the land use information produced through this integration was not based on an effort to resolve land use conflicts through a consultative process. Ironically, although models of participatory planning approach were long ago introduced and presented to the Ministry of Forests and Estate Crops by various different agencies, there has been no adoption or implementation of this approach in the field. ${ }^{39}$

Although the Spatial Management Act No. No. 29 of 1992 is specified in the RTRWP, the Ministry of Forestry and Estate Crops has an important de facto role in the implementation of forest and land allocation. The current interpretation of The Basic Forestry Law (UUPK) No. 5 of 1967, holds that all forest which has no clear ownership title is owned by the state. This interpretation has covered over the existence of adat (traditional) forest land claims as well as the presence of local people residing within the state forest. Consequently, government regulations based on the UUPK do not accommodate a process that would make "representation from below" possible.

Another issue related to forest land use is the high level of conflict of interest among different stakeholders who wish to maintain forest land as it is and those who wish to use the forest for other purposes, such as tree crop plantations and HTIs. According to an officer of the Land Use and Inventory Body in the Ministry of Forestry and Estate Crops, the current approach in integrating the TGHK and RTRWP tends to aim at expanding the area of tree crop plantations in each province. The main reason for this is the lobbying of large-scale companies to influence local governments to support investment in tree crop plantations in their region.

\section{Policy changes in the reformation era}

The prevailing economic crisis and economic and political reforms in Indonesia have both directly and indirectly increased the potential for pressure on natural forests. But at the same time, there is hope that fundamental policy changes may also happen which will correct some weaknesses in the forestry and tree crop plantation development that have occurred to-date. ${ }^{40}$

Given the environmental policy changes made by the Ministry of Forestry and Estate Crops thus far, it seems unlikely the government will recognize adat rights to forest and natural resources. Policy change has been more oriented toward redistribution of state forest management rights from large to small enterprises and to cooperatives. This effort, however, has been implemented without a clear concept of how to protect natural forests. For example, expired concession rights that were not extended have been distributed to smaller-scale forest enterprises, but without considering the change of existing sustained yield regulations. Implementation of this policy has been escalating business uncertainty and illegal logging, and it will increase degradation of the remaining natural forest. These facts show that efforts to correct past weaknesses in forestry and plantation development are still far from what one would hope for. 


\section{Recommendations and findings}

\section{Summary of findings}

1. The failure of HPHs to manage areas allocated to them has led the government to revoke concession rights. Degraded forests were then reclassified as reserve forests, as forests without definite functions, or to nonforest uses. The total forest area in this category is 8.3 million ha. If one adds to this the area of loggedover forest that will be rehabilitated, then as of June 1998 the area of degraded forest reached 16.57 million ha. If the average HPH term of operation is 20 years, then the increase of degraded forest averages 828,500 ha per year. Thus in an effort to save the remainder of natural forests, concession policy improvements are a very important step.

2. Regarding the area of timber plantations, about $22 \%$ of the total was natural forest prior to the establishment of the plantation. As of June 1998, therefore, 1 million ha ( $22 \% \times 4.6$ million ha) of natural forest has been converted to timber plantations. This means that timber plantations have played an important role in natural forest degradation.

3. Tree crop plantation development has led to the conversion of natural forests. The government intends to develop up to 6.7 million ha of tree crop plantations in the future. Tree crop plantations are allowed to reap the benefit of harvesting timber from natural forests cleared prior to the establishment of a plantation. This opportunity has often been abused by tree crop plantation companies that inflate the land area they need. In several provinces some companies were only interested in extracting the timber and then abandoning the land without replanting it.

4. The lack of competent institutions responsible for forest land use administration, together with the sociopolitical aspects of timber and tree crop plantations development, have exacerbated social problems related to forest land use. One of socio-political phenomena that encourage the degradation of natural forest is the diversification from HPHs to HTIs and tree crop plantations. When HPHs abandon degraded forests, HTIs and/or tree crop plantations are legalized to operate on this degraded land.

5. The main factor that encourages timber plantation development is the provision of subsidies and incentives to acquire forest land. These incentives have been used by the private sector to obtain timber from natural forest conversion and to obtain easy financial assistance from the government. This is indicated in the low rate of planting realization of $23.1 \%$. On the other hand, and ironically, the cheap price of timber from HTIs, and the investment uncertainty in the timber processing industries that will use plantation timber as their raw material, have in fact encouraged private companies to continue to apply for permits to develop HTIs.

6. Some private companies have in fact established HTIs without the subsidy provided through the Reforestation Fund. They chose to do this to avoid high transaction cost that result from the requirement to include state-owned corporations as partners and also from the high administrative costs for obtaining the subsidy. This fact shows that HTI operations are still profitable without the subsidy.

7. The recent inclusion of the Directorate General of Tree Crop Plantations in the new structure of the Ministry of Forestry and Estate Crops has not produced a policy to deal with overlapping claims to forest land. Issues related to the integration of TGHK and RTRWP still have no clear solution within this new structure.

8. Policies currently in force have not succeeded in resolving problems related to forest land use. There are indications that uncertainties in land use policy have yielded benefits to members of the private sector who intervene in the decision-making process of land and forest allocation. Moreover, government decisionmakers with their rent seeking behavior have benefitted from this situation.

\section{Recommendations}

In order to safeguard the remainder of Indonesia's natural forests, the government must change the status of primary natural forests within the production forest domain to permanent forest. These primary forests should not be converted to other uses. The development of large-scale timber and tree crop plantations should be directed toward unproductive production forests.

The gazetting of this forest area should take into account adat forests and the communities living in and around these forests. This can only be implemented if there are changes in the orientation of the Ministry of Forestry and Estate Crops, both at the central and regional levels, so that land allocation can be facilitated in the field. In accordance with this new orientation, forest and land redistribution must be planned by local governments and by regional offices of the Ministry of Forestry and Estate Crops because they can take into account the biophysical and socioeconomic conditions in their respective regions. 


\section{Acknowledgements}

Both authors are grateful to William D. Sunderlin who has provided the opportunity for this study to be undertaken, and also for his constructive comments on this paper. Special thanks also go to Dudung Darusman, Lesley Potter, Justin Lee, Anne Casson and Rita Lindayati for their valuable comments. The authors are responsible for errors of substance that may be found in this paper.

\section{Endnotes}

1 TGHK (Tata Guna Hutan Kesepakatan) is the functional classification of Indonesia's forest lands. The categories are: protection forest; conservation forest; production forest; and conversion forest (production forest that may be converted to other uses). The TGHK was established in 1983 by the Department of Forestry and agreed to by all provincial governments and other sectors. The RTRWP (Rencana Tata Ruang Wilayah Propinsi) is the spatial management plan of provincial land area as an elaboration of the Spatial Management Act of 1992. The spatial classifications according to theRTRWP are: protection forest; forest land cultivation area; and non-forest cultivation area. The two functional land classification systems have been integrated in their implementation since 1993.

2 In the Indonesian context, "critical lands" refers to degraded land that must be reforested.

350 Foreign Investment Enterprises Are Constructing Oil Palm Plantation (in Indonesian). Neraca, 14 July 1998.

${ }^{4}$ Minister of Forestry and Estate Crops Defined New Criteria for the Construction of Oil Palm Plantation (in Indonesian). Neraca, 11 April 1998.

5 Plantation State Owned Enterprises have been seen by foreign investors (in Indonesian). Kompas, 2 September 1998.

6 Perum Perhutani and PT INHUTANI are both stateowned enterprises engaged in forest management.

7 PT INHUTANI III starts developing oil palm (in Indonesian). Suara Karya, 18 June 1998.

8 PT INHUTANI I will enter estate business (in Indonesian). Suara Pembaruan, 23 June 97.

9 Neraca, 5 May 1998. Forestry State Owned Enterprises allowed to enter estate business (in Indonesian).

${ }^{10}$ Resulted from a discussion on "Empowering of People Economic Based on Natural Resources: The Case of Estate Crops and Forestry", 9 March 1999, held by Alliance for Sustainable Resources Management (K3SB), Bogor.

${ }^{11}$ State-owned forest area is defined as forest areas legally owned by the state. This area is not always covered by forest, so that an increase in area may legally mean that the forest area is increasing but the forest-covered area may actually be decreasing. In 1984, the state-owned forest was determined on the basis of the TGHK, whereas in 1997 it was changed as a result of integration of the TGHK and RTRWP.

${ }^{12}$ Based on reserve area for 44 HTIs have had legal aspect from Ministry of Forestry and Estate Crops Decree. Number of HTIs have had legal permit (Yearly Planing) are 132 units, consist of 22 units HTI Pulp, 47 units HTI non-pulp, and 63 units HTI-Transmigration. Government's plan yearly target of HTI is 250,000 ha. Ministry of Forestry and Estate Crops (1998).

${ }^{13}$ The regulation was changed to be No. 6/1999, but actually the subtance is not changed.

${ }^{14}$ Authors experience when they did feasibility study of HTI in Kalimantan and Sumatra in 1990 to 1995.

${ }^{15}$ MOFEC (1998) Re Arrangement of Large Scale Land Ownership and Forest Utilization in connection with the Resource Benefit Redistribution (in Indonesian). Jakarta. Data also derived from computer printouts obtained from MOFEC on 3 August 1998.

${ }^{16}$ State-owned enterprises in forestry are permitted into Tree Crop Business (in Indonesian). Neraca, 5 May 1998,

177 million ha forest area is converted into tree crop plantation (in Indonesian). Suara Pembaruan, 10 October 1997.

18 The interest of tree crops investor is still high. Suara Pembaruan, 26 Juli 1998.

${ }^{19}$ Save national park Bukit Tigapuluh (in Indonesian). Suara Pembaruan, 14 September 1998.

${ }^{20}$ Information derived from Ministry of Forestry and Estate Crops and Indonesia Business Data Center (Pusat Data Bisnis Indonesia), for various years.

${ }^{21}$ By July 1997 planted area of HTI Pulp is just 23,1\% (in Indonesian). Neraca, 7 November 1997.

2210 Tree crops corporations in Bengkulu will be withdrawn (in Indonesian). Suara Pembaruan, 22 August 1998.

23 Principal License of Estate Crops in Riau Province will be revoked (in Indonesian). Suara Pembaruan, 27 June 1998

${ }^{24}$ East Kalimantan Government will revoke 50 Estate Crops License (in Indonesian). Suara Pembaruan, 14 August 1998,

25 41,155 ha Community Estate Crops are invaded by 13 big companies (in Indonesian). Bisnis Indonesia, 3 September 1998,

${ }^{26}$ Press released by cooperation between Lembaga Bantuan Hukum Palembang and Konsorsium Pembaruan Agraria South Sumatra (in "Farmer Day", 24 September 1998). 
${ }^{27}$ Rising of Illegal cutting of HTIs in Lampung (in Indonesian). Kompas, 28 September 1998.

${ }^{28}$ PTPN II's Land is plundered (in Indonesian). Kompas, 14 July 1998.

${ }^{29}$ Ministry of Forestry and Estate Crops: I will check official who steal palm oil (in Indonesian). Sinar Pagi, 18 April 1998.

${ }^{30}$ Selling price of farmer's product is determined by market (in Indonesian). Sinar Tani, 14 October 1998.

31 Again, an increase of wage in estate crops business (in Indonesian). Sinar Tani, 14 October 1998.

${ }^{32}$ Coffee Farmers: Between Millionaire and Plundering Threat (in Indonesian). Sinar Tani, 26 August 1998.

${ }^{33}$ According to government regulation No. 7 of 1990 , one of the goals of timber plantations is to increase productivity and environmental quality.
${ }^{34}$ PT Kiani Hutani Lestari and PT ITCI Hutani Manunggal experience in East Kalimantan show when they were going to harvest their wood from HTI in 1995/ 1996, they difficult to sell the product.

${ }^{35}$ Authors' experience when they followed discussions about timber plantations feasibility study in the Department of Forestry in 1990-1994.

36 The statement is author's sense from following discussions about timber plantations held by government.

37 Transaction cost can be information, exclusion, contractual, and policing costs.

${ }^{38}$ One of the result of the socialisation of ecolabelling meeting conducted by Lembaga Ekolabel Indonesia and GTZ in Samarinda. 3-4 November 1998.

${ }^{39}$ Result of discussion with Ir. Diah Rahardjo, GTZ staff in Samarinda, East Kalimantan.

${ }^{40}$ In detail see William D. Sunderlin. 1998. 


\section{References}

Arifin.S and W.R.Susila,1998. Indonesia as a Major Oil Palm Producer: Prospects and Challenges. Center of Economic Studies, Research and Development Agency, Ministry. of Agriculture, Bogor.

Casson, Anne. 1999. The Hesitant Boom: Indonesia's Oil Palm Sub-Sector in an Era of Economic Crisis and Political Change. Programme on the Underlying Causes of Deforestation. Bogor, Indonesia: Center for International Forestry Research.

Ministry of Forestry, 1996. Forest Resources Statistic in Indonesia II (excluded Java). National Forest Inventory Project. Directorate General of Inventory and Land Uses Planning. Department of Forestry collaboration with FAO. Jakarta.

Ministry of Forestry, 1997. Report on Accountability of Minister of Forestry Period 1996/1997 (in Indonesian). Jakarta.

Ministry of Forestry and Estate Crops, 1998a. Re arrangement of Large Scale Land Ownership and
Forest Utilization in connection with the Resource Benefit Redistribution (in Indonesian). Jakarta.

Ministry of Forestry and Estate Crops. 1998b. Direction, Strategy and Policy of Forestry and Estate Crops Development. Government's Respond of Working Report of Komisi III DPR (House of Representative). 1997/1998. Jakarta.

Directorate General of Estate Crops. 1998. Report of PIR Implementation and Valuation. MOFEC. Jakarta.

Sunderlin, William D. 1998. Between Danger and Opportunity: Indonesia's Forests in an Era of Economic Crisis and Political Change. September 23, 1998. http://www.cgiar.org/cifor/

Susila, W.R, 1997. Economic Model of the World Crude Palm Oil (in Indonesian). Center of Economic Study, Agricultural Research and Development. Bogor.

Susila, W.R, 1998. Development and Prospects of the Main Plantation Commodity (in Indonesian). Center of Economic Study. Agriculture Research and Development. Bogor. 